\title{
Laughter and the Limits of Identity: Joyce, Beckett and the Philosophical Anthropology of Laughter
}

\section{Adrienne Janus}

\section{Q OpenEdition \\ 12 Journals}

\section{Electronic version}

URL: http://journals.openedition.org/etudesirlandaises/3410

DOI: 10.4000/etudesirlandaises.3410

ISSN: 2259-8863

\section{Publisher}

Presses universitaires de Rennes

\section{Printed version}

Date of publication: 30 July 2013

ISBN: 978-2-7535-2673-0

ISSN: 0183-973X

\section{Electronic reference}

Adrienne Janus, «Laughter and the Limits of Identity: Joyce, Beckett and the Philosophical Anthropology of Laughter », Études irlandaises [Online], 38-1 | 2013, Online since 30 June 2015 connection on 01 May 2019. URL : http://journals.openedition.org/etudesirlandaises/3410 ; DOI 10.4000/etudesirlandaises.3410 


\title{
Laughter and the Limits of Identity: Joyce, Beckett and the Philosophical Anthropology of Laughter
}

\author{
Adrienne JANUS \\ University of Aberdeen
}

Abstract

Following philosophical anthropologists such as Helmuth Plessner, Georges Bataille, and Jean-Luc Nancy, as well as cultural linguists such as Joseph Vendryes, this article explores the event of laughter in the works of Joyce and Beckett as a vocalised bodily response to limit conditions, one that has a privileged place in attendance to events of death and birth as liminal occasions in the constitution of the self, of the community and of art.

Keywords: Laughter, Joyce, Beckett, identity, death, liminality.

\section{Résumé}

S'appuyant sur les travaux d'anthropologues de la philosophie comme Helmuth Plessner, Georges Bataille, ou Jean-Luc Nancy, ainsi que sur ceux du linguiste culturel Joseph Vendryes, cet article traite du rire dans l'oeuvre de Joyce et de Beckett comme une réponse corporelle vocalisée à des conditions limites, réponse qui joue un rôle priviligié, face à ces événements que sont la mort et la naissance, considérés comme des occasions liminales pour la communauté, pour l'art et pour l'individu de se constituer.

Mots clés : Rire, Joyce, Beckett, identité, mort, liminalité.

"Haw! You heard that one? A beauty. Haw! Hell! Haw! So. Haw! Haw! Haw! My laugh, M-?I beg your pardon. Like Tyler? Haw! My laugh, Mr. Watt. Yes. Of all the laughs that strictly speaking are not laughs, but modes of ululation, only three need detain us, I mean the bitter, the hollow and the mirthless. These correspond to successive, how shall I say successive... suc... successive excoriations of the understanding ${ }^{1}$..."

"Haw! You heard that one? A beauty!" This line from Watt inaugurates one of Beckett's more famous performances of laughter, one which presents laughter as a "mode of ululation, corresponding to successive excoriations of the unders-

1. Samuel Beckett, Watt, London, John Calder, 1953, p. 54. 
tanding 2". The laughter heard here, and throughout Beckett's work, resonates nicely with the "duodisimally profusive plethora of ululation" that excoriates the listening reader's understanding in the "funferall" of Joyce's Finnegans Wake 3. To attend to the particular resonance of this laughter, laughter performed in the work of both Joyce and Beckett as a "mode of ululation, corresponding to successive excoriations of the understanding", this article follows my previous study, "Listening to Laughter in Joyce and Beckett", and treats laughter not as a side-effect of humour or comedy, but as an acoustic, aesthetic and existential event that indicates a vocalized bodily response to limit conditions ${ }^{4}$. These limit conditions would not merely be those of the psyche, where laughter emerges as a vocalized bodily response to occasions of extreme joy or misery, or to occasions when we confront the limits of our understanding. Nor would they merely be the limiting historical and socio-political conditions which form the background against which the works of Joyce and Beckett emerge: on the one hand, Ireland's "colonial and post-colonial insecurities and discontinuities", including "the islandwide instability of political life in the years leading up to independence (and its wearying repetitiveness after partition), its unstimulating provincialism, and the peculiar and uneasy relationship many Irish writers have had with the English language"; on the other, the world war that ultimately lead Joyce and Beckett to self-imposed exile in Paris. Rather, the most interesting, and most prominent, performance of laughter in the work of Joyce and Beckett is as a vocalized bodily response to those liminal occasions fundamental to human existence as such, namely birth and death. Why laughter, rather than tears, would be the privileged response to these limit conditions has not only to do with what might be identified as particularly Irish cultural habits, habits communicated across the political, historical and linguistic limits dividing "primitive", Gaelic-speaking Ireland from the "modern" Anglo-Irish Ireland that was both Joyce's and Beckett's point of departure. It also has to do with certain philosophical and aesthetic ideas regarding laughter that Joyce and Beckett were in part exposed to in Paris in the 1930s. This brings us to a notion suggested by the line from Beckett's Watt, "Haw! You heard that one? A beauty!", a line that calls attention to laughter as both an acous-

2. Ibid., p. 54.

3. James Joyce, Finnegans Wake, London, Faber, 1975, p. 6, 13.

4. See Adrienne Janus, "From "Ha he hi ho hu. Mummum" to "Haw! Hell! Haw!': Listening to Laughter in Joyce and Beckett", Journal of Modern Literature 32.3, 2009, p. 144-165. This article sets the theoretical basis for the present one, in distinguishing laughter as an acoustic event from laughter as a side-effect of humour, humour literary critics usually tend to identify in Joyce's and Beckett's work as belonging to an international modernist lineage of "cosmic comedians" (see Ruby Cohn, "The Comedy of Samuel Beckett", Yale French Studies 23, 1959, p. 11-17) or a particularly Irish comic tradition (see Vivian Mercier, The Irish Comic Tradition, Oxford University Press, 1962).

5. John Wilson Foster, "Irish Fiction", Vol. III of The Field Day of Irish Writing, edited by Seamus Deane, p. 9371136, Derry, Field Day, 1991, p. 938. 
tic and an aesthetic event ${ }^{6}$. Laughter here, and throughout the works of Joyce and Beckett, produces a presence that disrupts language, one that emerges and disappears at the limits of representation. As such, laughter as an event may have some affinities to the notion of "événement" developed by Alain Badiou: a sudden manifestation ("pur surgissement") whose emergence and disappearance resists, or is exempt from, the laws of representation as of conceptual categorization ${ }^{7}$. As a vocalized bodily response to limit conditions, and as a sudden manifestation of embodied presence, the event of laughter can be listened to and sensed as something that touches us with the resonances of its vibrations, but cannot be grasped as an identifiable image, concept or object. In this way, laughter not only marks the limits of normative modes of socio-political and literary representation. As suggested by Jean-Luc Nancy when he writes, "laughter is pure presentation, or the art of pure presentation: nothing less than the essence of art, than the desire of art, to come into presence in the presentation", laughter also has a fundamental relation to poiesis ${ }^{8}$. It is associated with the birth of new modes of writing, modes of writing that attempt to produce a presence that can be sensed in the rhythmical and tonal disruptions that laughter enacts in literary language, but which cannot be represented directly9.

The works of Joyce and Beckett not only present or perform laughter in interesting ways, they also foreground laughter as an event that has a privileged place in attendance to events of mortality and natality - death and birth as liminal occasions in the constitution of the self, of the community, and of art. Although the events of death, birth and laughter, in their existential, social and aesthetic modalities, touch upon each other in ways that do not allow for easy separation, my analysis will focus on one main line of enquiry, under the title, Laughter, Death and the Birth of Style. Here, I will address how the event of laughter accompanies events of mortality in Joyce's and Beckett's work: how laughter marks the limits of national identity, but also gives birth to the particular styles of writing that Joyce and Beckett will develop, a writing that pushes literary language to the limits of its possibilities.

6. Samuel Beckett, Watt, op. cit., 54.

7. Alain Badiou, Beckett: l'Increvable Désir, Paris, Hachette, 1995, p. 42, p. 44. This and all subsequent translations are my own, unless otherwise indicated.

8. Jean-Luc Nancy, "Wild Laughter in the Throat of Death”, MLN, 102.4,1987, p. 719-736, p. 725.

9. Although not addressing Jean-Luc Nancy's conception of laughter per se, my article on the senses of listening in Nancy's work bears some relation to the claims made here. See Adrienne Janus, "Listening: Jean-Luc Nancy and the "Anti-ocular" Turn in Continental Philosophy and Critical Theory", Comparative Literature 63.2, 2011, p. $182-202$. 


\section{橉 “Tears and Laughter, so much Gaelic"? Laughter, Death, and the Birth of Style}

There are two strangely complementary scenes from Joyce's and Beckett's work where laughter emerges as an event that marks the limits of language and of identity, and accompanies the event of mortality - the death of individuals as well as of linguistic communities. In both scenes, the sound of laughter emerges alongside the sound of Gaelic, that dead or dying language that Irish nationalists had been trying to revive as something fundamental to Irish identity and to Irish art. This laughter would be an aesthetic event in so far as it suggests something about the ways in which both Joyce and Beckett, as self-proclaimed Irish writers, attempt to develop a literary style that moves past the limitations of the realism dominating the English literary tradition and the romanticized "Gaelic" literary tradition espoused by the Irish Literary Revival.

The first scene is one of the more strangely comic moments from Beckett's Molloy. Molloy has just run over the pet-dog of a certain Mrs Lousse. Lousse has just dug a grave and buried the dead dog and as she finishes her task she begins to laugh in a very strange way. Laughter here, quite playfully, is an existential event: for Lousse, laughter is a vocalized bodily response to the limits of consciousness when faced with the death of her canine companion; for Molloy, the listener, laughter occasions the death of his own identity as conscious self and rebirth as Lousse's dogsbody (Molloy, immediately after this scene, will take the dog's place as Lousse's domestic pet). What is most interesting in this scene however is the strange sound of Lousse's laughter:

When she (Lousse) had finished her grave she handed me the spade and began to muse, or brood. I thought she was going to cry, it was the thing to do, but on the contrary she laughed. It was perhaps her way of crying. Or perhaps I was mistaken and she was really crying, with the noise of laughter. Tears and laughter, they are so much Gaelic to $\mathrm{me}^{10}$.

One can hear Molloy's claim, "Tears and laughter, they are so much Gaelic to me", as Beckett's own laughter at claims that Gaelic, a dying language, could ever be used in art or in life to represent Irish identity. But what strikes the listening reader here is the way in which this strange sound of "crying, with the noise of laughter" emerges and disappears as an acoustic event at the limits of language, an event that seems to fascinate Molloy precisely because he is unable to interpret it or to identify its significance. This would not only be the way which Beckett probably heard Gaelic, but would become, in a certain way, the way in which Bec-

10. Samuel Beckett, Molloy, London, Picador, 1979, p. 35. 
kett's writing would hear all language: namely, as an acoustic event which emerges and disappears at the limits of one's capacity to capture or fix its meaning or significance and, perhaps because of this, exerts a mysterious, almost auratic power on those who attend to it.

Laughter in this scene is thus also an aesthetic event, as suggested by Beckett's use of those very pregnant terms, "muse, or brood" in the first line: Lousse begins to "muse or brood" before giving birth to laughter. Laughter here, as throughout Beckett's work, "gives birth aside a grave" (to recall those famous lines from Waiting for Godot); it "gives birth aside a grave" to produce a writing that marks the presence of that which is unknown and unknowable ${ }^{11}$. As Georges Bataille suggests,

There is something intoxicating in laughter $[\ldots]$ related to the invasion of the unknown, to the elimination of a part of this world which we consider as the world known in all the parts generally seen as a whole. If someone dies, for example, it is true that a familiar order is deeply altered, and that we must face the substitution, before us and in spite of us, of something that we know by something unknown to us, for example, the presence of the dead, or more precisely, the absence of the living ${ }^{12}$.

Read against Bataille, this scene in which Molloy hears "crying, with the noise of laughter" as so much Gaelic, would seem to acknowledge, even invoke, the presence of dead Gaelic culture - its palpable absence from the living culture of Ireland. But this laughter might also be heard as a response to the limit conditions under which Beckett composed his work. For Beckett began writing Molloy upon returning to Ireland after spending the duration of World War II in France, a return upon which he would face his mother's death and family dissolution. It is at this point that Beckett himself located his beginnings as a mature writer, a day during which perhaps he began to muse or brood and, as he writes, "realised that I knew nothing. I sat down in my mother's little house in Ireland and began to write Molloy ${ }^{13}$ ". One might say that it is out of deference to the dead, to the unknown, that Beckett begins to write Molloy, not in English, but in French, thus substituting the "known" familiarity of his English mother tongue with the "unknown', adopted second language. Indeed, all Beckett's writing can be heard as a writing born of laughter as a response to the limit conditions of mortality, a kind of writing that, as Beckett famously said, "has nothing to express, no means to express, together with the obligation to express", but a writing which attempts

11. Samuel Beckett, Waiting for Godot, New York, Grove Press, 1954, p. 57-58.

12. Georges Bataille, "Unknowing: Laughter and Tears", October 36, 1986 p. 89-102, p. 98.

13. Cited in W. J. McCormack, From Burke to Beckett, Cork, Cork University Press, 1994, p. 414. 
to produce the presence of that which is at the limits of knowing, at the limits of life and death ${ }^{14}$.

The scene where Molloy hears "crying, with the noise of laughter" as "so much Gaelic" in fact replays a scene from Joyce's "The Dead", where the noise of laughter emerges alongside cries in Gaelic, both of which are heard as acoustic events at the limits of language. This scene that fuses the acoustic events of laughter and Gaelic follows shortly after one in which Miss Ivors, an Irish nationalist, has accused Gabriel of being a "west Briton" - of trying to pass as English rather than acknowledging his "true Irish" identity and learning Gaelic.

"Beannacht libh", cried Miss Ivors, with a laugh, as she ran down the staircase.[...] Gabriel asked himself was he the cause of her abrupt departure. But she did not seem to be in ill humour: she had gone away laughing. He stared blankly down the staircase ${ }^{15}$.

This scene where laughter emerges and disappears alongside the sound of Gaelic, a Gaelic phrase which means "farewell", might be read as Joyce's own farewell to Gaelic, and to the Gaelic language movement that wanted all Irish writers to write in their "national" language. But the way in which Gabriel responds to this laughter suggests that something more is going on. For this laughter is the first in a series of acoustic events to which Gabriel's powers of interpretation can only respond blankly, events which emerge and disappear at the limits of the power of consciousness to identify, to interpret, and to control them. The second acoustic event linked to laughter in this story is the traditional Irish song, "The Lass of Aughrim", a song which is heard to conjure up the presence of the dead, namely, the dead lover of Greta, Gabriel's wife, from the Gaelic-speaking West of Ireland. The story ends with a moment where Gabriel achieves a kind of communion with the dead, a communion enacted not by laughter, but by tears, that other, non-vocalized, bodily response to limit conditions:

The tears gathered more thickly in Gabriel's eyes and in the partial darkness he imagined he saw the form of a young man standing under a dripping tree. Other forms were near. His soul had approached that region where dwell the vast hosts of the dead. He was conscious of, but could not apprehend, their wayward and flickering existence. His own identity was fading out into a grey impalpable world: the solid world itself which these dead had one time reared and lived in was dissolving and dwindling ${ }^{16}$.

14. Beckett, Three Dialogues, London, John Calder, 1953, p. 124.

15. Joyce, "The Dead", Dubliners, London, Penguin Classics, (1914) 2000, p. 196.

16. Joyce, "The Dead", p. 224-225. 
It matters little how we interpret Gabriel's tears - whether they are "read" as a response to the death of his own, illusory visions of love for his wife, or as a response to the limitations of his own feelings in comparison to the intense passion Greta had felt for her dead lover. What is important is the impact of the bodily response of Gabriel's tears upon normative modes of perceptual consciousness. For the tears that "gathered more thickly" in Gabriel's eyes occlude the faculty of visual perception, and with it, the powers of consciousness to identify, objectify, and interpret phenomenal reality. These tears that block Gabriel's powers of selfconscious reflection also dissolve his perception of material reality, so that both his identity, and that of his present reality, dissolve into the "grey impalpable world" inhabited by the shades of the dead.

This dissolution of material reality occasioned by Gabriel's tears, and the lyrical flights of imagination that accompany it, however, belong to a dead, or dying, literary realm that Joyce's later works will not resurrect - to the romantic metaphysics of Yeats and the revivalists. In subsequent works like Ulysses and Finnegans Wake, it is not Gabriel's tears, but the laughter and song associated with Miss Ivors and Greta, that re-emerge as events which produce a kind of communion that momentarily fuses the material presence of living and dead, without binding them to limiting representations of "national" language or "Irish identity".

There are of course other, more complex, reasons why both Joyce and Beckett's writing privileges laughter, as a vocalized bodily response to limit conditions, over tears, as a (usually) non-vocalized bodily response to limit conditions. In the first instance, these reasons may be inferred from the descriptions Helmuth Plessner offers in Laughter and Crying: A Study of the Limits of Human Behaviour. This classic work of philosophical anthropology conceives of laughter and crying not as side-effects of particular psychic or emotional states (psychic or emotional states that can be interpreted according to the hermeneutic norms that dominate literary criticism), but as particular dispositions of our status as embodied, and not merely conscious, beings in the world. For Plessner, laughter indicates a disposition characterized by "openness, immediacy, eruptivity", whereas crying is characterized by "closure, mediacy, gradualness ${ }^{17 "}$ ". Following from Plessner, one might say that the sudden eruption of laughter as a vocalized bodily response has an immediate impact not only on the body of the laugher, but on those who hear it. In this way, laughter is capable of infecting others whose body responds with laughter in turn, thus opening a mode of phatic, embodied communication with others when no adequate linguistic response can be found. Laughter, further-

17. Helmuth Plessner, Laughing and Crying: A Study of the Limits of Human Behaviour, translated by James Churchill and Marjorie Greene, Evanston, Northwestern University Press, 1970, p. 146. 
more, in serving as a surrogate for linguistic communication, not only marks the limitations of language as the privileged mode of human communication. Unlike crying, which closes down speech and communication in the silence of a body that collapses in on itself, laughter momentarily disrupts or punctuates speech with embodied vocalizations whose production is the primitive, originary basis of linguistic communication itself, thus calling attention to the fundamental elasticity of language as communicative material.

These descriptions of laughter may go some way towards explaining why Joyce, whose desire to destroy and revitalize the English language from "the roots of its vocables" inspired Ulysses and Finnegans Wake, and Beckett, who once famously declared his desire to tear apart "that terrible materiality of the word surface" in the creation of a "literature of the un-word', would privilege the event of laughter over tears as a means of testing the possibilities and limits of literary language ${ }^{18}$. They do not yet fully explain however why the event of laughter, and particularly the kind of laughter that might be heard as "so much Gaelic", has such a privileged place in attendance to the event of death in Beckett's and Joyce's work. There are numerous answers to this question, answers that range from the anthropological, to the philosophical, to the cultural linguistic. I shall offer a series of examples corresponding to these three fields of study, examples that, taken as a whole, suggest the complex cross-identifications of Joyce's and Beckett's writing as both Irish and European, local and international, primitive and modern.

The first answer has to do with what happens at an Irish wake, which, in traditional Gaelic culture, involved ritualized performances of laughter around and with the body of the recently deceased. As anthropologist Ilana Harlow suggests:

The wake marks a liminal moment in the social life of an individual. In the period between death and burial, a person being waked is physically still part of the community and is present at the social gathering, yet is unable to participate. [...] The wake must deal with the question of how to relate to a person in a liminal state of being, how to integrate such a being into the social scene ${ }^{19}$.

How exactly does the laughter performed at an Irish wake allow the living to relate to "a person in a liminal state of being"? Here we can turn to Helmuth Plessner's formulation, and say that laughter brings the living momentarily to the limits of conscious thought and intentional action, where "in laughter, the diso-

18. Cited in Richard Ellmann, James Joyce, Oxford, 1984, p. 559; Samuel Beckett, "German Letter of 1937", Disjecta, edited by Ruby Cohn, London, John Calder, 1983, p. 172.

19. Ilana Harlow, "Creating Situations: Practical Jokes and the Revival of the Dead in Irish Tradition", The Journal of American Folklore, 110.436 (1997): 140-68, p. 110. 
riented body takes over the response from it [the mind], no longer as an instrument for action, speech, movement or gesture, but simply as a body ${ }^{20 "}$. Laughter then, in momentarily releasing the living body from conscious direction, allows the living to engage in a momentary communion with the dead, those embodied presences which are eternally beyond the limits of conscious thought and intentional action.

Georges Bataille offers a more complex reading of laughter as an existential event that attends death at the Irish wake, which he introduces by declaring that,

The Irish custom of the "wake" is little known, but it could still be observed at the end of the last century. It's the subject of Joyce's last work, Finnegans Wake. [...] a wake involves the death of another, but in such a case, the death of another is always the image of one's own death ${ }^{21}$.

Bataille turns to the wake, and to what he calls the "angoisse gaie" or "gay anguish" manifested in laughter at the image of death, as an alternative to the way in which death has become instrumentalised in Western culture and thought. In other words, we don't confront death as such, but rather see death as a media spectacle, as entertainment, or as a political act serving some ideology or cause; or we see death as an accident, an abnormal failure of the system, whether that of the individual's biological system, or of a nation's social system, both of which are ostensibly programmed to care, support and maintain life. For Bataille, the apparently purposeless laughter at death, and the loss of the capacity for self-conscious reflection that is occasioned by this laughter, forces the laugher to experience the mortal limits of identity while still in the midst of life:

If I perceive death "gaily", it doesn't mean I turn away from that which I fear, saying "it's nothing" or "it's false". Rather, gaiety, linked to the work of death, provokes anguish; gaiety is accentuated by my anguish and exasperates this anguish in turn; finally, this gay anguish [l'angoisse gaie], provokes a hot-cold sensation of absolute self-sundering [l'absolu déchirement], whereby it is my own joyous laughter that destroys me, but where dejection would follow joy if I were not completely and excessively torn apart by laughter ${ }^{22}$.

This anguished gaiety [angoisse-gaie] of laughter that attends the event of death, and sunders the material body of language from fixed representations or easily identifiable meaning, is manifest nicely in the following passage from Finnegans Wake, where the event of laughter marks the dissolution, and reincarna-

20. Plessner, Laughing and Crying: A Study of the Limits of Human Behaviour, 67.

21. Georges Bataille, "La Mort et le Sacrifice", Vol. 12 of Euvres Complètes, Paris, Gallimard, 1970, p. 341.

22. Ibid., p. 342. 
tion, of the mythical Irish figure, Finn or Finnegan: "Hohohoho, Mister Finn, you're going to be Mister Finnagain! Comeday morm and, O, you're vine! Sendday's eve and, ah, you're vinegar! Hahahaha, Mister Funn, you're going to be fined again ${ }^{23}$ !" Laughter here not only marks the process of linguistic morphogenesis where Finn becomes Finnagain, and vine is distilled into vinegar. It also catalyses what Beckett, in describing the language of Finnegans Wake, had called the endless process of "verbal germination, maturation, putrefaction" that pushes literary language to the limits of its possibilities ${ }^{24}$.

This brings us to the third and final reason - or set of reasons - why laughter has such a privileged place in Joyce and Beckett's work alongside events of mortality, death and destruction. This reason has less to do with Irish Wakes than with Paris in the 1930s. In Paris at that time, during the period when Beckett was helping Joyce by taking dictation of Finnegans Wake, he was at the École normale supérieure as a lecteur d'anglais. Among his colleagues was a linguist named Joseph Vendryes, who wrote the first etymological dictionary of Irish. According to Vendryes, the etymology of the Irish word for laughter, gàire, can be traced back to verbs which mean "to make noise, to shake violently, to hit or push", verbs which not only incorporate the noise and violent bodily movements associated with laughter, but which are also associated with the noise and violence of war:

Old Irish used the verb tibim, soon replaced by the verb gáirim, derived from the substantive gáire. [...] These come from a root actually meaning "noise': irl. gáir "shout or cry", particularly "cri de guerre"/"war cry" whence "guerre"/"war'. [...] The idea of noise and that of movement are moreover connected, and agree quite well with the idea of "laughter" as a noisy spasm of the human body. This verb in effect unites the sense of "laughter" with that of hitting, striking, pushing 25.

Vendryes not only suggests that "gaire", the Irish word for laughter, is linked both to the French "cri de guerre" or "battle cry", but also that it is also the origin of both the French and English words "gay" (as in the "angoisse gaie" Bataille suggests is produced by laughter).

In a strange way, Vendryes confirms the etymology, if not the essentialist politics, of Matthew Arnold. Arnold associates the extremes of aesthetic virtuosity that, for him, are characteristic of Celtic literary style, with laughter as a response emerging from a fundamental liminality of "the impressionable Celt":

23. Joyce, Finnegans Wake, op. cit., p. 5.

24. Samuel Beckett, "Dante... Bruno. Vico. Joyce”, in Disjecta, p. 29.

25. Joseph Vendryes, “L'Expression du Rire en Celtique”, Études Celtiques 3 (1938): 38-45, p. 39, p. 43. 
Our word gay, it is said, is itself Celtic. It is not from gaudium, but from the Celtic gáir, to laugh; and the impressionable Celt, soon up and soon down, is the more down because it is so his nature to be up - to be sociable, hospitable, eloquent, figuring away brilliantly ${ }^{26}$.

For Arnold, Celtic laughter and literary style are not only linked to the liminal "nature" of the Celt, to an almost manic liminality of joyous highs and lows that resonates uncannily with the hot-cold "angoisse gaie"/"joyous anguish" that Bataille associates with laughter at the Irish Wake. This liminality is also linked to both laughter and literary style conceived of as responses to limiting historical and political conditions (i.e. inevitable death and defeat in battles against the English), whereby Celtic poetry tries to "make up to itself for being unable to master the world and give an adequate interpretation of it by throwing all its force into style, by bending language at any rate to its will ${ }^{27}$. Arnold's etymology, as we have seen from Vendryes, may be correct. And Vendryes, etymology would also seem to confirm Arnold's notion that laughter may be used to bend or break language conceived of as a normative, hegemonic system of representation, a notion that will be reinforced shortly when we attend to the productive mutations and disruptions that Joyce's and Beckett's use of laughter enacts upon their writing. Arnold's association of laughter with liminality, furthermore, although incorrect in its essentialist particulars, can, in a general sense, refer to the liminality Plessner suggests is occasioned by laughter as a response that momentarily releases the living body from the control of consciousness, a response that both Harlow and Bataille draw attention to as particular properties of the laughter traditionally occurring at Irish wakes. Arnold is most markedly incorrect, however, in his assertion that laughter, and the literary style associated with it, is merely a compensatory response for an inability to "master the world and give an adequate interpretation of it". For laughter suggests another mode of world-appropriation than that structured according to the dichotomies of mastery and servitude; and it suggests another relation to both the world and to language than that given by interpretation as that mode whereby both world and word are relegated to the status of objects whose meaning must be penetrated, controlled and contained by a subjective consciousness.

There is one moment in particular from Joyce's Finnegans Wake where the event of laughter suggests an encounter of worlds given not as the opposition of discrete identities, but as the fusion of resonant, vital presences. This laughter, furthermore, can indeed be heard as "so much Gaelic", in so far as this laughter is a

26. Matthew Arnold, "On the Study of Celtic Literature", in Complete Prose Works, edited by RH Super, p. 291397 , p. 343.

27. Ibid., 343 . 
noise that violently shakes up language and is associated with war and defeat. It does so in a way that reveals the limitations of national identity and national languages conceived (as Arnold does) in terms of English mastery and Irish subjection. This is a moment when Joyce invokes Ireland's history of invasion and colonization as a party hosted at the "Casaconcordia" by Vercingetorix and "his Ann Van Vogt" (Shan Van Vogt or Mother Ireland). Here, the acoustic event of laughter not only marks the noise and violence accompanying the love and war waged between foreign and native bodies. It resurrects the buried history of miscegenation between foreign and native tongues. This laughter is heard, for example, in the question Mother Ireland asks of Vercingetorix, her Gaulish-Breton suitor, "A thaw bron orm, A' Cothraige, thinkinthou gaily ${ }^{28}$ ?". In this line, the resonance of the Gaelic phrase, "Ó tá brón orm, a Chothraighe, [an] tuigeann tú Gaedhealg" ("O I'm sorry, friend, do you speak Irish") fuses with that of the English phrase, "Do you think gaily?" This hybrid linguistic body mutates even as the listening reader attends to it, pulsating "gaily" between English and Gaelic. It produces the noise and the violent bodily movement whose fusion informs the word "gáire" - the Irish word of laughter. The event of laughter, heard as "so much Gaelic", is used not only to enact violence against the material body of language, and upon the conceptual containments of normative systems of language and representation. It is also a productive force capable of resurrecting the material presence of the dead - those dead buried in the bed of letters and laughter that is the "allaphbed" of Finnegans Wake, composed of "Miscegenations on miscegenations" of all those who "lived und laughed ant loved end left ${ }^{29}$ ".

"Loud, Heap miseries upon us yet entwine our arts with laughters low. Ha.He. Hi.Ho. Hummm ${ }^{30}$." With this one eventful line, Joyce invokes the muse of laughter that has given birth to works that challenge normative systems of literary, as well as socio-political, representation, systems that have "heaped miseries" upon those vital presences that cannot, or will not, be contained within its bounds. The writing born from this laughter may challenge constructs of communal identity as represented by the nation or by national language by producing the vital presence of bodies that share the same space, as in Joyce's work. Or it may challenge constructs of individual identity as represented by a rational consciousness by producing the vital presence of a body capable of giving birth to the self as an opaque, yet materially sensible, presence, as in Beckett's work. In either case, this laughter, as an acoustic, existential and aesthetic event, emerges as a vocalized bodily response to limit conditions, a response that (as suggested by the Irish word for laughter) violently shakes the body of the laugher and the body of lan-

28. Joyce, Finnegans Wake, 54.

29. Ibid., 18.

30. Ibid., 259. 
guage, giving "voice" to the joyous anguish that attends both the death of old as well as the possible emergence of new modes of art and life.

It may be the case that those writers whom we identify, for a lack of a better term, as Irish, may be more alive to laughter, insofar as they are more aware of the limitations of normative systems of representation, as to the limit conditions of existence, namely birth and death. Perhaps this laughter belongs precisely to a culture caught between a "primitive" Gaelic presence that, since the famine of 1848, has been living "astride a grave" and a "modern" Anglo-Irish or British one associated with dominant cultural, socio-political norms. Or perhaps this laughter belongs equally to a culture at the limits of Europe, caught between the "British" isles and France. Whatever the case may be, the literary laughter of Joyce and Beckett is exemplary, but not singular. As illustrative examples of the prominence of laughter in Irish writing, one might turn to two writers whose work emerged in the period directly before and shortly after that of Joyce and Beckett. The first, J.M. Synge, profited in ways similar to Joyce and Beckett from border crossings to France, and his work, like that of Swift, was canonized in André Breton's Anthologie de l'Humour NoirlAnthology of Black Humour, which claimed that this kind of "dark" laughter must always contain "un peu de terre d'Irlande"/"a bit of Irish soil ${ }^{31}$ ". It is only after a sojourn in France, where Synge attended Marie Henri d'Arbois de Joubainville's lectures on Celtic mythology, that he would be inspired to travel to the Aran Islands. Here, Synge would be struck by the strange laughter of the Gaelic speaking islanders, whose "wild jests... half-sensual ecstasy of laughter... and ungovernable eyes, seem to represent some old type found on these few acres at the extreme border of Europe ${ }^{32}$ ". The second writer who follows in what might be called a genealogy of Irish laughter is Ciaran Carson, a contemporary poet from Belfast - a physical space marked all too prominently by borders, by limitations imposed by concepts of national identity and national language. Carson responds in part to the socio-political and linguistic limitations of contemporary Irish writing, as of contemporary Northern Irish politics, by crossing the border to France to produce a telling translation of Rimbaud's poem "L'Éclatante Victoire de Sarrebruck"/ "The Amazing Victory of Sarrebruck ${ }^{33}$ ":
À droite, Dumanet, appuyé sur la crosse
De son chassepot, sent frémir sa nuque en brosse,
Et: "Vive l'Empereur!"-Son voisin reste coi...

31. André Breton, Anthologie de l'humour noir, Paris, Éditions du Sagittaire, 1950, p. 17.

32. John Millington Synge, The Aran Islands, Dublin, Maunsel, 1911, p. 448-9.

33. Arthur Rimbaud, "L'Éclatante Victoire de Sarrebruck" in Ciaran Carson, "Poster Advertising the Amazing Victory of Sarrebruck", The Alexandrine Plan: Versions of Sonnets by Baudelaire, Mallarmé, Rimbaud, Loughcrew, Gallery Books, 1998, p. 9-11. 
In the stalls, another half-wit rules Britannia

With his rifle, and demands that all Hispania

Be Napoleanized. His chum sniggers, "Heh, heh, heh..."

The last line of Rimbaud's poem ends in silence: "Vive l'empereur - son voisin reste coi"/"Long live the emperor - his neighbour keeps mum". Carson's translation, on the other hand, fills this silence with vocalized laughter: "Be Napoleanized. His chum sniggers, "Heh, heh, heh". Carson's translation of silence into vocalized laughter not only marks the limits of the extension of empire into the future. It suggests another kind of sovereignty than that delimited by imperial, or post-imperial, political systems of governance. This sovereignty is indicated by Helmuth Plessner as the sovereignty of a self who, through laughter, "loses mastery of the body, renouncing his relation to his body, yet [thereby] proving still a sovereign comprehension of the incomprehensible, a power in impotence, a liberty and grandeur under constraint. He knows how to find a response even when there is nothing left to say ${ }^{34 "}$.

34. Plessner, op. cit., 78. 